\title{
Columbus, Corsair, and the Pinzón brothers, Pirates, in the Mediterranean before 1492
}

\section{Francesc Albardaner i Llorens}

\begin{abstract}
L'auteur présente ici des documents qu'il a découvert dans les archives espagnoles au sujet des carrières pratiquement inconnues des frères Pinzón avant qu'ils aient navigué avec Christophe Colomb jusqu'en Amérique en 1492. Le matériel éclaircit les activités des frères en tant que corsaires et suggère que Colomb aurait participé à ces entreprises.
\end{abstract}

\section{The dark side of history}

Too often, popular history, as presented in the mass media and in many basic textbooks, clings to the romantic historiographical perspective of the nineteenth century. The arrival of Christopher Columbus and the Pinzón brothers on American shores in 1492 is not only considered a "major discovery," but has also transformed Columbus into one of the most important historical figures in history. Indeed, the United States continues to celebrate "Columbus Day" on October 12, while Central and South America commemorate "Dia de la Raza," a popular holiday that originated in Franco's Spain, even though few are aware of what "race" they are talking about.

Our understanding of Christopher Columbus's role in history has changed dramatically, however, from 1892, when the $400^{\text {th }}$ Anniversary of his first voyage was celebrated, to the most recent centennial in 1992. Over the course of a century Columbus was transformed from "saint" to "villain," from universal hero to initiator of the largest genocide in human history. Today it is hard to even imagine Count Rosselly de Lorgues proposing that the Pope canonize Columbus as a saint.

Rewriting history to conform with a romanticized view of the past usually occurs when historians conceal or alter, either by commission or omission, individual characters or events to make them more "respectable." For example, historical accounts of late $15^{\text {th }}$ century European corsairs and pirates have too often "overlooked" the fact that many respected sailors and merchants of the period owed their fortunes to such irregular activities. Although there has always been a legal difference between corsairs and pirates, when analysing the final results, we have to admit that many mariners played on both sides of the fence.

Ongoing research in Spain's rich archives continually brings to light new documents that can alter our perspective on important historical personalities. This paper presents a new document in regard to Vicente Yañez Pinzón and several others

The Northern Mariner/le marin du nord, XXI No. 3, (July 2011), 263-278 




Illustration 1. First page of document concerning the galleass Ferrandina, signed by Joan de Coloma, royal secretary to King John II, dated 29 February 1468. It includes a 
Illustration 1 (continued.) transcription of a letter from John II, at Tarragona, to the bailiff of Valencia, 23 February 1468. Two extracts from this part (vide infra, p. 271) show that King Ferrante of Naples was half-owner of the vessel, in whose honour she was named. The other owners were Florentine merchants of the Vespuccio family. (Royal Archive of Valencia, Batllia, vol. 1154, pp. 189v-193r. Reproduced by permission.)

concerning the galleass Ferrandina, including links to Christopher Columbus's participation in an important naval battle.

\section{Protohistory of the pinzón brothers before 1492}

The Andalusian-born brothers, Martin Alonso and Vicente Yañez Pinzón, sailed with Christopher Columbus on his first voyage to America in 1492. Together with the "Vizcaino,"1 Juan de la Cosa, they were responsible for the expedition and command of Columbus's three ships. What we know about the role of these four men in the famous voyage is totally overshadowed by the figure of Columbus himself. Moreover, there has been little documentation about the Pinzón brothers prior to 1492. Until at least 1950, the only reliable information about the "protohistory" of the Pinzón brothers came from the statements of several sailors from Palos who participated in legal proceedings between Diego Colón and the Crown after Columbus's death. Because Vicente Yañez Pinzón continued to participate in voyages of discovery after 1492, there is additional information available on his activities, but Martin's death in 1493 effectively removed the elder brother from the historical record.

Despite the lack of documentation in regard to the Pinzón brothers before 1492 , several articles have been written about them since the end of the nineteenth century that are listed in the bibliography below. These essays include references to the naval activity of members of the Pinzón family in the Canary Islands or African Guinea prior to 1492, as well as their participation in acts of war against Portugal around Gibraltar and in the Atlantic .

The first pre-1492 reference to Vicente Yañez Pinzón was uncovered by the Catalan historian Núria Coll i Julià and published in a Spanish historical journal in $1950 .^{2}$ It was a protest by the councillors of the city of Barcelona presented to the King of Castile dated 1 March 1477. The document complained of the damage caused by a ship under the command of Vicente Yañez Pinzón to two vessels owned by Mateu Capell, a Barcelona merchant. Capell's goods were stolen from an illegally captured ship belonging to Galceran Andreu in the port of Alfachs in southern Catalonia. Accused of piracy were Diego de Mora and Juan Rodriguez Estoriano from Seville and Vicente Yañez Pinzón of the port of Palos, the captains of the three ships.

The councillors' accusation was extremely harsh because no one expected subjects of Ferdinand, the King of Castile and heir to the Crown of Aragón, to attack a

1 At the end of the fifteenth century, all sailors from the territories of northern Spain facing the Bay of Biscay or Vizcaya were considered as "vizcainos" in the kingdom of Castile.

2 Núria Coll i Julià, "Hispania X,” Revista Española de Historia (1950), 596. 
Catalan vessel belonging to subjects of his father, King John II, ruler of the Catalan confederation. Ferdinand responded to this unexpected attack with a royal letter dated 14 April 1477 addressed to all authorities, terrestrial and maritime, that forbade piratical acts by his subjects of Castile against the subjects of King John II.

The second document relating to the naval activities of Vicente Yañez Pinzón and his elder brother, Martin, in the Mediterranean, was published by Francisco Morales Padrón in the Revista de Indias in $1961 .^{3}$ From this document we know that in the year 1479 the Pinzón brothers attacked a ship owned by citizens of the city of Ibiza and, after taking possession of the vessel and cargo, carried it back to the port of Palos in Andalucia.

The third document relating to Vicente Yañez Pinzón prior to 1492 refers to a piratical act committed in 1484 by Martin de la Borda, mariner of Fuenterrabia, in which a cargo of corn destined for Genoa was stolen from a ship belonging to Vicente Yañez Pinzón. In this case, Vicente Yañez Pinzón was the victim and not the aggressor. This document was published by Juan Manzano y Manzano and his daughter in his important monograph Los Pinzones y el Descubrimiento de América published in 1988 (Madrid: Ediciones de Cultura Hispánica).

Very recently, I have had the pleasure of finding another document related to Vicente Yañez Pinzón at the Arxiu Històric de Protocols de Barcelona, belonging to the Barcelona Association of Notaries. It is a letter dated 27 February 1477, and is therefore the oldest document yet known concerning Vicente Yañez Pinzón. It also refers to the piratical attack committed in the port of Alfachs by three Andalusian ships against a vessel owned by Galceran Andreu. The most important parts of this document, written in Latin, are:

Noverint universi Quod Ego Matheus Capell Mercator civis Barchinone ex certa sciencia confirmo et ordino vobis magnificum Alvero de Nave militem, Consiliarium et capitaneum generalem Classis maris serenissimi et potentissimi domini Regis Castelle licet absentem tanquam presentem procuratorem meum certum et specialem ac etiam ad subscripta generalem itaque especialitas generalitati non deroget nec e contra videlicet ad petendum exhigendum recipiendum recuperandum et havendum pro me et in nomine meo a Diego de Mora, Johannes Rodriguez Storiano, civitates Civille. Vicentio Anes Pinson ville de Palos patronis calavera / Fferdinandi Daries Sayavedre mariscal; Petri vasques de Sayavedre / et Gundisalvus de Stuniyega / dominorum ipsarum calaverarum, compianonis et dominacionis dicti domini Regis Castelle et ab propis dominis ac ab aliis etiam personis indetentis seu obligates et bonis ipsorum omnes illa Saquas lanorum et alias res et merces que per ipsos manu armati michi depredate fuerunt in portu dels Alfachs Dertuse principatus Cathalonie a balanario Galcerandi Andreu qui illich pro me mercabat de lanis et inde apoca vel apocas...etc.

$3 \quad$ Francisco Morales Padrón, Revista de Indias 83 (1961). 




Illustration 2 Power of attorney given by Matheu Capell, merchant in Barcelona, to Alvaro de Nava, admiral of the navy of Castile, given in Barcelona, 27 February 1477, and dispatched by Lluis Jorba, notary. This is the oldest known reference to Vicente Yañez Pinzón, and identifies him as a pirate captain. (Collegi de Notaris de Barcelona, Arxiu Històric de Protocols de Barcelona, Notari Lluís Jorba (238/12) 1472/1481, Plec Doc. Diversa. Reproduced by permission.)

...ac Barchinone XXVII die mensis ffebruari anno a nativitate Domine MCCCCLXXVII Signum Mathei Capell predictum hec laudo et firmo. ${ }^{4}$

This document is a power of attorney given by Matheu Capell to Alvaro de Nava, admiral of the navy of Castile in the strait of Gibraltar. It reveals the names of the three pirate captains: Diego de Mora and Juan Rodriguez of Seville, and Vicente Yañez (or Anes) Pinzón from the town of Palos, actually known as Palos de la Frontera. The location was the port of Alfachs in Catalonia, on the southern side of the Ebro River delta. In the document, the port is called "Portu dels Alfachs Dertuse," because it was the natural port of the town of Tortosa. Galceran Andreu, captain of the captured ship, was transporting goods, mainly wool, belonging to the merchant Matheu Capell, a wealthy citizen of Barcelona. The owners of the three caravels were Fernando Daries Saavedra, Pedro Vazquez Saavedra and Gundisalvo de Stuñiga, all Andalusians. 
Gonzalo (or Gundisalvo) de Stuñiga had been the lord mayor of the harbour town of Palos until 1492, when the Crown of Castile acquired half-ownership of this port and replaced Stuñiga by Diego Gutierrez. At that time, the sailors of Palos had extensive experience in organizing expeditions to Guinea in search of gold and slaves, in open confrontation with the Portuguese. These expeditions involved considerable secrecy, however, as did any piratical activities against Portuguese vessels between the Canary Islands and the Iberian peninsula on their return journey from Guinea. Thus the sailors of Palos, and the Pinzón brothers among them, had considerable opportunities for mounting attacks on shipping in Atlantic waters and earned themselves a small fortune through the sale of captured goods and slaves.

No wonder the Crown selected Palos as the ideal port for launching Columbus's first voyage instead of choosing one of the larger Andalusian ports, such as Seville, Cadiz or Puerto de Santa Maria. Firstly, Palos was under direct royal control and secondly, the local sailors were considered the most experienced sailors in Atlantic waters, both in piracy and in the gold and slave trade, "qualities" that could be considered by the Crown as the necessary "know-how" for the American voyage.

The Pinzón brothers' experience with piracy in the Mediterranean opens up the possibility of a personal relationship between them and Christopher Columbus prior to their 1492 voyage, but due to the absence of actual documentation and the fact that the record of naval activities for the Pinzón brothers is later than 1476, I think we must limit further speculation for the time being.

\section{Christopher Columbus, corsair before 1492.}

Friar Bartolomé de Las Casas in his Historia de Indias ${ }^{5}$ copied a letter written in 1501 in Seville or Cadiz by Christopher Columbus to the "altos Reyes." In this letter, Columbus declares that he began sailing very early in his youth and affirms that he has been a sailor for more than 40 years ("Ya pasan de 40 años..."). If so, Columbus began sailing in 1461 or earlier, but despite his lengthy career, we know very little beyond a few details recorded by his son, Fernando. ${ }^{6}$ From his biography, we can deduce four phases in Columbus's maritime career. First as a captain of a ship in the navy of Aragon (1470?1473?); second as a crew member of Guillaume de Cazenove Coulon (1473?-August 1476; third, he was involved in a discovery voyage to Iceland and Greenland in a LusoDanish expedition (1476-1477) and lastly embarked on voyages to La Mina and Cabo Verde under the Portuguese flag (1477-1484).

Based on Columbus's claim that he had visited "all the East and the West" before 1470, several authors accept initial voyages by Columbus in the Mediterranean as far as Chios and Rhodes. This paper, however, will focus only on his naval service in the Mediterranean under Réné d'Anjou, Count of Provence and King of Aragon. It is a period of Columbus's life that has often been dismissed, especially by Italian scholars, as

$5 \quad$ Fray Bartolomé de Las Casas, Historia de Indias, Tome 1, chapter 3.

6 Fernando Colón, Vita di Cristoforo Colombo, descritta da Ferdinando, suo figlio e tradotta da Alfonso Ulloa (1571). 
pure invention and personal vanity.

The sole documentary source for this period is an undated letter sent by Columbus to the Catholic Kings, and copied by his son Fernando Colón, which states:

And in another letter, that he wrote from Hispaniola in the month of January in the year 1495 to the Catholic Kings about the diversity and errors that may happen in deciding the ship's course and pilotage, he says:

And it happened to me, that king Reinel, who God has taken with him, sent me to Tunisia, in order to capture the galleass Fernandina, and just when we were near the island of San Pietro, near Sardinia, somebody told us, that, together with the galleass there were two sailing vessels and a "carraque", fact that alarmed the crew, that decided not to continue sailing forward, but sail back to Marseille in order to get another ship and more sailors to join us; and I, seeing no way of forcing their decision, I conceded them what they were asking for; but changing the needle of the compass, I ordered to unfold sails to the wind, late in the evening; and next day, at sunrise we were at sight of cape Cartaghe, even if the crew was convinced of returning to Marseille.

Scholars have argued about the accuracy of the previous text while trying to determine Columbus's skill as a seafarer. Without the original letter, it is difficult to determine whether Columbus sailed to Cape Carthage in Tunisia, or to Cape Cartagena in Spain. The doubt created by this lack of clarity affects the arguments of both sides. But this short text contains other facts that may help determine whether it is true or not.

\section{King Reynel and the Catalan civil war}

Determining what happened in regard to the prosecution of the galleass Ferrandina told in the letter quoted above is extremely important, since it affects our understanding of other aspects of Columbus's life. The first clue is his use of the title "king Reinel" for the Count of Provence (among his many other titles). Although often referred to as "le bon roi Réné," because of his honorific title of king of Jerusalem, Réné d'Anjou was not actually a king. For a brief period, when Catalonia took up arms against King John II after 1462, following the successive elections of King Henry IV of Castile and of the Constable Peter of Portugal by the Catalans, Réné d'Anjou was proclaimed King of the Catalan Confederation (Crown of Aragon) by the Catalan government. Significantly, the Catalans used precisely the form "King Reynel," or "King Reinel," when referring to their newly selected lord, Réné d'Anjou, between 1466 and 1472.

Columbus's letter to the Catholic Kings was probably written in Castilian, and Fernando Colón seems to have copied it directly from the original text. Afterwards, Alfonso Ulloa translated it into Italian, but both transcribers retained the form "King Reynel," which seems to reflect the original. Assuming that Columbus referred to "King Reynel" because he was writing during the period when Réné d'Anjou was effectively King of the Catalans, the nautical adventure with the galleass Fernandina had to have taken place between July 1466 and October 1472. 


\section{The galleass Ferrandina or Fernandina}

According to his letter to the Catholic Kings, Columbus was captain of a ship serving the interests of Réné d'Anjou against King John II, whose fleet included the galleass Ferrandina or Fernandina. Fortunately, additional information about the vessel can be found in the archives in Valencia and Barcelona.

The galleass Ferrandina, also known as Fernandina, was named in honour of King Ferrante of Naples, bastard son of the late King Alfonso of Aragon, and nephew of King John II of the Catalan Confederation, Alfonso's brother. It seems that the Ferrandina was jointly owned by King Ferrante and several Florentine merchants. The earliest reference to this ship is found in the Archive of the Kingdom of Valencia in a letter sent by King John II from Tarragona to the "Battle General" in Valencia, dated 17 February 1468. In that letter, the king agrees to permit the galleass Ferrandina to sell the goods that the ship brought from Italy, even if some of the deliveries would fall into enemy hands, ("de nostres rebelles o de nostres enemichs, ço es del Duch Reynel e duch Joan,..."). Note that John II, when referring to his enemy, Réné d'Anjou, never uses the title of king but only that of duke.

From another document of the Royal Archives in Valencia, ${ }^{7}$ dated Monday, 29 February 1468, we know that the captain of the galleass Ferrandina was "Piero Johan Vezpuxe" (Pietro Giovanni Vespuccio). ${ }^{8}$ In this document is included the transcription of the letter of John II brought by captain Vespuccio, dated 23 February 1468, in Tarragona, in which the king affirms: "and for respecting his highness Don Ferrando, our nephew, that we love as our own son, that has some part of the ownership of that

7 Llibre de la Batllia de Valencia de Mossèn Honorat Berenguer Mercader, ARV; Batllia n. 1154 , p. $189 \mathrm{v}-193 \mathrm{r}$.

8 The commercial contacts between Valentian and Florentine merchants were very important in the second half of the 15th century. The transcription of the following document, demonstrates early contact between Lluis de Santángel, the future sponsor of Columbus's discovery voyage, with the Vespucci merchants of Florence, the family of Amerigo Vespuccio, Columbus's friend and collaborator:

Friday, 12 September 1477:

"Notum sit cunctis quod Ego, Ludovicus de Sentangel, Mercator civis Valencie, heres universalis bonorumque omnium et jurum que quondam fuerunt honor Ludovici de Sentangel, patris quondam mei, mercatoris civis dicte civitate ut constat de dicta herencia ultimo illo testamento receptor per discretum Jacobum Carnicer, notarius publicus Valencie, die secunda mensis septembris anno a nativitate dominis MCCCCLXXVI. Et perundem notarius publicatus in mensis novembris anno predicto MCCCCLXXVI. Gratis et scienter dicto norem ffacio constittuo et ordino procuratorem meum certum et specialem ac generalem ad infrascriptam vos magnificum Guillermum de Pasci, florentinum, absente tanquam presente videlicet ad petendum, habendum, exhigendum et reaprendum per me et nome meo a magnifico Piero de Julian Vespuchi, milite florentino, quaius peccunie quantas res campas et merces per illum debitas michi Nome predicto tamen cause et albaranis quam sive illis et debitis que receptis seu recepisse confessus suntis apochas albarana absoluciones et disfunciones pacta anuencias transacciones et composiciones ,etc." (ARV, Notary Jaume Salvador, Protocol 1997 - Year 1477). 
galleass...."("Volem empero per respecte del Illustrissimo Rey don Ferrando nostre molt car nebot com a fill, quis diu haver part en la dita galeaça,..." ). In that same letter, the king also specifically names "the galleass of Florentines, called La Ferrandina, that has arrived once again in that port (beach of Valencia)."

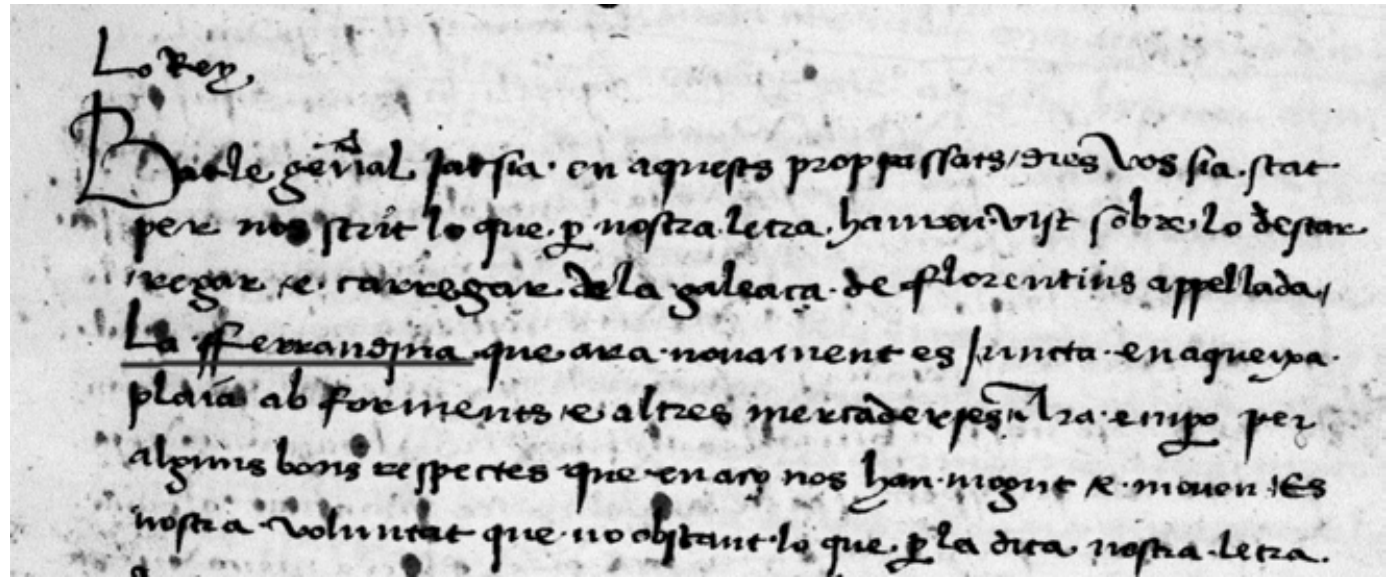

Illustrations 3 and 4. Two extracts from the document (vide supra, $p$. 264) concerning the galleass Ferrandina, show that King Ferrante of Naples was half-owner of the vessel, in whose honour she was named. The other owners were Florentine merchants of the Vespuccio family. (Royal Archive of Valencia, Batllia, vol. 1154, pp. 189v-193r. Reproduced by permission.)

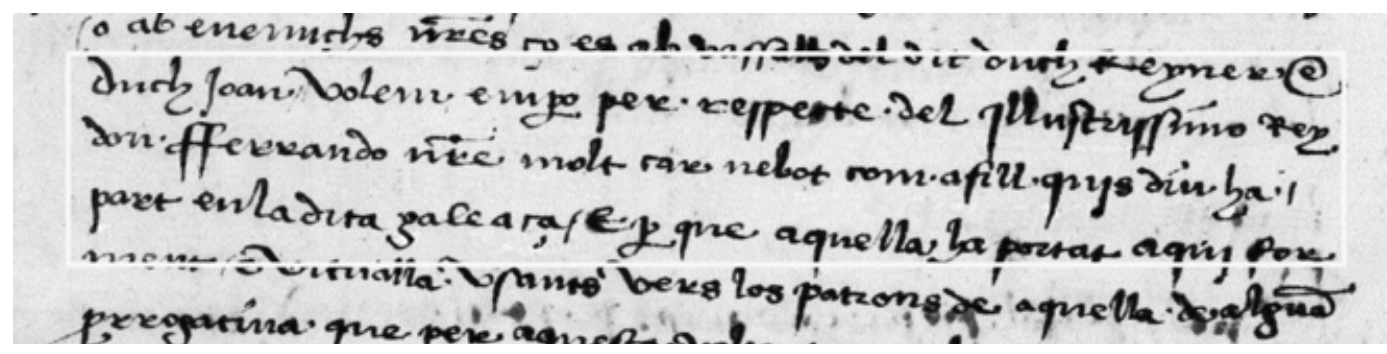

A letter from the bailiff of Valencia, Honorat Mercader, to the king, dated 5 March 1468, states: "I got your letter from the hands of the captain of the galleass of the Florentines, called Ferrandina, etc..." The king's willingness to confide a letter to the crew of the ship demonstrates his trust in their loyalty. During the civil war between the Government of Catalonia and John II, control of maritime commerce was essential in order to deprive their enemies of both arms and food. These documents prove not only the true existence of the galleass called La Ferrandina, but her crew's loyalty to the cause of John II in the Catalan civil war.

Four years later, when Barcelona was the only town still resisting the siege by the army and navy of John II, ${ }^{9}$ we find, among the letters sent between the councillors of

9 In the "Arxiu Històric Municipal de Valencia" (AHMV) are several letters written by John II explaining the situation of the terrestrial and naval siege of Barcelona at the end of the 
Barcelona and their King, Réné d'Anjou, the following references to the Ferrandina:

Letter to the King, 26 August 1472:

The very last day, when we wrote to your Majesty, there were in this beach (of Barcelona) XI ships, big and small, of the enemies, and IIII galleasses. Today several ships have departed together with two galleasses, remaining only the Farnandina, two venetian vessels and three whalers or not so big vessels, and it is believed that these six vessels will return with three galleasses.

Letter to the King, 6 September 1472:

Because the belly does not allow any further delay, there remain only IIII enemy vessels: the Farrendina, one Venetian and two whalers, ... ${ }^{10}$.

According to these letters, the galleass Ferrandina played an important part in the siege of Barcelona, in the final moments of the Catalan Civil War, as John II battled Réné d'Anjou for control of the Catalan Confederation. The war ended in the Principality of Catalonia on 16 October 1472 with the signature of the Peace of Pedralbes between the city of Barcelona and John II.

After the war, an insurance document dated 14 August $1478^{11}$ indicates that the galleass Ferrandina continued her normal commercial activities between the port of Barcelona and the port of Naples.

Based on the above information, it is possible to attempt to date the timing of Columbus's attempt to capture the Ferrandina in Tunisian waters. After the fall of Barcelona, in our opinion, there was no further reason for chasing and capturing the galleass Ferrandina. Therefore, it is most likely that the events described by Columbus

Catalan Civil War. Letter sent by John II from Badalona, near Barcelona, on 11 July 1472 to the councilors of the city of Valencia:

"Estimats e feels nostres: los fets nostres stan huy en tal disposició que esperam ab la ajuda de Déu haurem properament la ciutat de Barchinona e si sem ajudats en les necessitats que concorren/ nos per terra tenim la gent necessaria per a strenyer e opprimir la dita ciutat/per mar tenim quatre naus, dos baleners, cinch galeres e segons los sentiments que havem es molt necessari que la dita armada de mar sia reforçada per quant se enten segons havem entes que los enemichs condueexen naus e donen diligencia en socorrer la dita ciutat...". (AHMV: Manual de Consells - A39; 1471 - 1473).

Free translation: "The current facts are today in such disposition, that we hope that, with the help of God, we will conquer soon the city of Barcelona. We have enough personnel in our army to maintain the terrestrial siege. For the naval siege we have four ships, two whalers, five galleys and our opinion is that this current navy should be reinforced, because our enemies are very diligent in gathering vessels in order to succour Barcelona."

Among the vessels that were coming to help the navy of Réné d'Anjou to defend Barcelona was the fleet of Guillaume de Cazenove Coulon with seven warships.

10 Arxiu Històric de la Ciutat de Barcelona, Lletres Closes, Notari Joan Brujó 1471-1473.

11 AHPB, Notari Narcís Gerald Gili 1476/1478. 
must have taken place in 1471 or in the first half of 1472, when he would have been trying to prevent the ship from joining in the siege of Barcelona.

\section{The corsair navy of Réné d'Anjou}

In the second half of the fifteenth century, European kingdoms did not maintain permanent naval structures or a standing navy. Navies were formed as and when required. For example, it was only towards the end of the Catalan Civil War (1470/1471), that Réné d'Anjou decided to establish a temporary naval force under the command of Fray Carles de Torrelles, Catalan chevalier of the Order of Rhodes, in order to support Barcelona against an ongoing naval siege. Another famous captain of this fleet was Antoni Setantí, of Barcelona, also known as Francesc Antoni Setantí or Franci Antoni Setantí. In 1455, Setanti is known to have sailed from Barcelona to Rhodes for commercial purposes, ignoring the risks of encountering the Turkish navy.

Under the terms of their employment, Réné d'Anjou's corsair navy was composed of captains who agreed to risk their own ships and crews for 20 percent of the value of all enemy vessels captured in the King's cause. Unfortunately, no one supervised the captains once they set sail. In the Archives Nationales of Paris ${ }^{12}$ there is documentary proof that Captain Antoni Setantí attacked vessels belonging to states not at war with Réne d'Anjou. This constituted piracy. From this and other historical evidence, it seems very likely that Christopher Columbus was a member of Réné d'Anjou's corsair fleet. He lived in Marseille from at least 1470 until 1473, and most probably sailed in the corsair navy of Fray Carles de Torrelles and Franci Antoni Setantí. Interestingly, this little-known period of Columbus's life does not appear in his existing biographies, especially those by Italian scholars. Why?

Traditionally, the history of the discoverer of the New World, as told through Genoese documents, depicts Cristoforo Colombo as a poor, 21 to 22-year-old weaver in Savona or Genoa in 1473. It is hard to reconcile that image with the experienced seafarer of 1470-72 that we have just seen. Not only was Columbus well past youth in terms of sailing, but he was far more likely to be working as a pirate than weaving. The reluctance of some Italian scholars to accept a darker version of Columbus is understandable.

\section{Columbus as corsair with Guillaume de Cazenove Coulon}

The Catalan Civil War, considered to have lasted for nearly a decade after 1462, did not actually end for all the combatants in 1472. Once the King of France became involved, first in support of John II and then on the side of Réne d'Anjou, he occupied the Catalan counties of the Roussillon and the Cerdagne in northern Catalonia and failed to return this land after the peace treaty of Pedralbes, thus extending the war between France and the kingdom of Catalonia for nearly twenty years. Several scholars admit that this "Roussillon War" did not really end until late in 1493.

$12 \quad$ P 1334.3, fol.7v. 


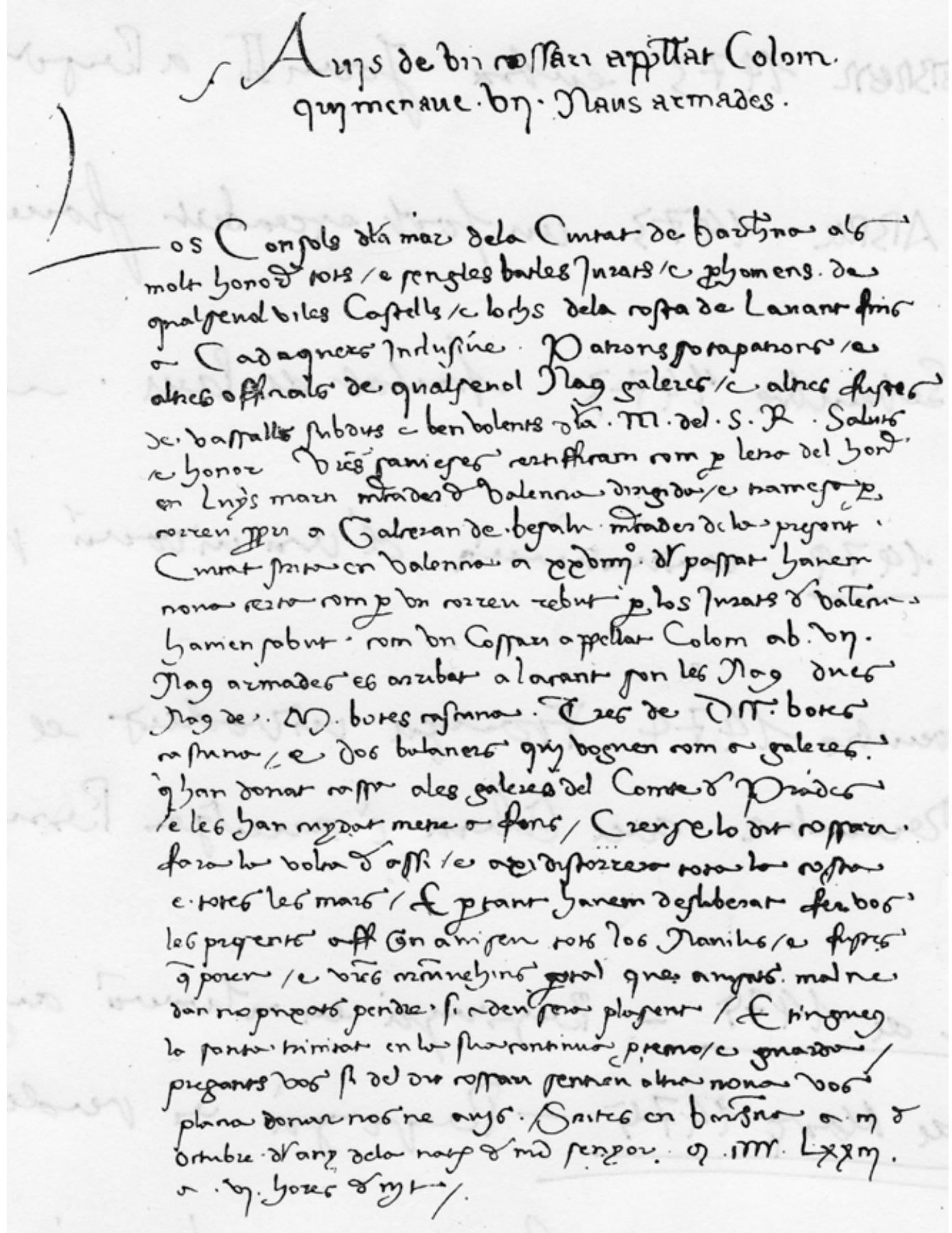

Illustration 5. "Avis de un cossari apellat Colom qui menave VII Naus armades" ("Warning letter about a corsair called Colom who commands seven armed ships") sent by the Consolat de Mar (Maritime Authority) in Barcelona to all ports, harbours and coastal 
Illustration 5 (continued.) villages of the Catalan Confederation, 3 October 1473. "Colom" refers to Guillaume de Casenove Coulon, that in the Catalan confederation was known as "Colom" and in the Kingdom of Castile was known as "Colón." Guillaume de Cazenove Coulon was vice-admiral in France and operated in the English Channel as a pirate from his port of Honfleur. Following is a loose translation of the main body of the document: " $a$ corsair known as Colom with seven armed ships has arrived at Alacant... This fleet has persecuted the galleys of the Count of Prades and ... sent [them] to the bottom of the sea. It is believed that this corsair will turn round from that place and will sail along all the coast. And therefore we have informed you of this news in order that you may alert all the ships and vessels ... so that ... no harm will occur to them..." (Arxiu Històric Municipal de Barcelona, Consolat de Mar, Llibre de Deliberacions, 1-I,I-2, pp.19r-19v. Reproduced by permission.)

Returning to our study of Columbus as a corsair, it is important to remember that his son and biographer, Fernando Colón, asserted that Columbus sailed with the famous French corsair Guillaume de Cazenove Coulon for several years. In August 1476, Columbus took part in a naval battle off Cape Saint Vincent in Portugal. He fought on the side of the Franco-Portuguese navy against four Genoese and one Flemish vessels. Italian scholars also deny this episode in Columbus's life, especially after discovering that Guillaume de Cazenove Coulon was a French corsair, and not a Ligurian Colombo, corsair or pirate. Another reason for denying the participation of Columbus on Cazenove's side in this battle was the fact that he fought against Genovese ships. The Genovese historian Pessagno could never demonstrate that Columbus was among the Genovese crews in this battle, although he found documents containing the lists of all members of these crews.

Nevertheless, it is not only highly probable but reasonable to expect that Columbus continued his corsair activities under Cazenove Coulon. At the end of the Catalan Civil War, to help Réné d'Anjou and maintain his control over the territories of Rousillon and Cerdagne, Louis XI of France sent a fleet under corsair Guillaume de Cazenove Coulon from Honfleur to Marseille. In mid-September 1473, Cazenove sailed back for home, stopping en route at the end of September to completely destroy the Catalan navy of the Count of Prades in front of Alacant (Alicante). During the recent conflict, the Count of Prades and Cardona had been the most illustrious and strongest ally of King John II in Catalonia. This naval attack was not considered piracy, however, since Cazenove did not capture any ships or goods. Instead, he simply sank all the ships and killed the crews in a clear act of revenge against John II and his supporters following the final defeat of the army and navy of Réné d'Anjou in Catalonia the year before.

The document that demonstrates the truth of the naval battle between the ships of Guillaume de Cazenove Coulon and the navy of the Count of Prades and Cardona in front of Alacant, is a warning letter sent by the Consolat de Mar (Maritime Authority) of Barcelona to all the ports, harbours and coastal villages of the Catalan Confederation dated $3^{\text {rd }}$ October 1473. This document says that the news of the naval disaster was known thanks to a letter sent by Lluís Martí, Valentian merchant, to Galceran de Besalú. Merchant in Barcelona, the $29^{\text {th }}$ of September 1473 at "six hours in the morning." 
Therefore this naval battle may have taken place one or two days before 27 or 28 September $1473 .^{13}$

Italian scholars find it very difficult to connect "their" Cristoforo Colombo with Guillaume de Cazenove Coulon, whose naval activities were based in the harbour of Honfleur and whose natural maritime domain was the English Channel. Therefore they deny that Cazenove and Columbus ever sailed together. But, given the fact that Cazenove was in the Mediterranean in 1472-1473, and specifically in Marseille, and that the temporary navy of Réné d'Anjou was dismantled after his defeat in 1472 leaving Columbus without a job, it seems reasonable to think that Columbus would leave Marseille and begin a new life sailing under the flag of France in the crew of Guillaume de Cazenove. One possible link between the French and the Provencal corsair navies may be Jean de Bueil, who was both a councillor to Réné d'Anjou and Admiral of France, serving Louis XI. Père Anselme, in his famous Histoire Généalogique et Chronologique de la Maison Royale de France includes Guillaume de Cazenove among the members of the Bueil family.

\section{Conclusion}

A Spanish proverb says: "Dios los cria y ellos se juntan", meaning that persons with similar affinities and moral values tend naturally to become friends or allies. We have no evidence of previous contact between Christopher Columbus and the Pinzón brothers before 1492, but it seems clear that they recognised each other as experienced sailors with a very long "curriculum vitae," full of legal and illegal adventures. Martin Alonso Pinzón was undoubtedly a natural leader among the sailors of Palos and an enemy to be feared by the Portuguese sailors. He readily accepted Columbus as a fellow seaman highly skilled in maritime affairs, not only due to Columbus's own merits but also to his association with Guillaume de Cazenove Coulon, the infamous French pirate, with whom Columbus sailed for several years. In fact, the fearsome reputation of the vice-admiral of France may have influenced Columbus to change his original surname to "Colón" from 1492 onwards. $^{14}$

If we accept that Columbus and the Pinzón brothers, whether corsairs or pirates, were great sailors of their time, with extensive naval experience, we must conclude that

13 The Warning Letter of the Barcelona Consolat de Mar, dated 3 October 1473, was first published by Francesc Carreras i Candi in his article "Colom i altres corsaris atacant les costes catalanes (1473- 1474)," Butlleti del Centre Excursionista de Catalunya (July 1927), 244. In this article Francesc Carreras supposed that the corsair called "Colom," who comanded seven armed vessels, was Columbus himself, but in next articles about this document admited that the corsair "Colom" was the French vice-admiral and famous corsair Guillaume de Cazenove Coulon.

This document is preserved at the Historical Archive of the City of Barcelona and its full reference is: AHCB: "Llibre de deliberacions" (Consolat de Mar, 1-I, I-2, f. 19)

14 See the chronicle of Diego de Valera, Chapter XXI: "Del caso acaecido al capitán de la flota francesa llamado Colón en el cabo de Santa Maria que es a treynta y seis leguas de la ciudad de Cadiz." 
the Christopher Columbus who sailed with the Pinzón brothers in 1492 is not the same Christoforo Colombo of the Assereto's document, who was still a simple commercial agent in 1479 .

The documents relating to the galleass Ferrandina have reconfirmed Columbus's early service as a ship captain to Réné d'Anjou, King of Aragón and count of Provence, in the naval base of Marseille. From the documents cited in this paper, and evidence dating the naval episode of the Ferrandina to 1471-1472, two important conclusions follow. First, in 1472, Columbus was older than the 21-22 years suggested for the Genoese Cristoforo Colombo. Most likely aged between 25 and 30 at the time, Columbus was probably born between 1442 and 1447. Second, accepting that Columbus lived in Marseille from circa 1470 to 1473, and knowing that Guillaume de Cazenove Coulon sailed to Marseille in 1472-1473, it confirms the accuracy of Fernando Colón's story of his father's naval experience under Cazenove Coulon.

As we have seen, new documents shed new light on the lives of Christopher Columbus and the Pinzón brothers. Some are useful in reaffirming the activities of the brothers in Mediterranean waters, but others not only confirm the veracity of the "Historie" of Fernando Colón and the activities of his father as a corsair, but also generate new data that casts serious doubt on the accuracy of the Genoese version of Columbus's history.

Finally, while the Muslim territories of North Africa or Turkey spawned the most feared pirates in the western Mediterranean during the second half of the fifteenth century, there was plenty of piratical activity carried out by subjects of Christian kingdoms and Mediterranean republics against each others' ships. What is unusual for this period are the occasional incursions of Atlantic-based pirates, such as the Pinzón brothers or Guillaume de Cazenove Coulon, into Mediterranean waters.

\section{Bibliography:}

Álvarez de Toledo, Luisa Isabel. “África versus América: La fuerza del paradigma. Centro de documentación y publicaciones islámicas. Junta Islámica, 2000.

Asensio, José Maria. "Martín Alonso Pinzón.” Colección de Libros Escogidos. La España Moderna: Madrid.

Aznar Vallejo, Eduardo. "La expedición de Charles de Valera a Guinea. Precisiones históricas". En la España Medieval vol. 25 (2002), 403-423.

Carreras I Candi, Francesc. "Colom i altres corsaris atacant les costes catalanes (1473-1474)," Butlletí del Centre Excursionista de Catalunya (July 1927), 244.

Coll I Julià, Núria. "Vicente Yañez Pinzón, descubridor del Brasil, corsario en Cataluña," Revista Hispania X (1950), 594-597.

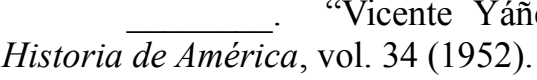

Coló, Fernando. Vita di Cristoforo Colombo, descritta da Ferdinando, suo figlio e 
tradotta da Alfonso Ulloa. London: Dulau $\neg$ Co, 1867.

Favier, Jean. Le Roi René. Librairie Arthème Fayard, 2008.

Fernández Duro, Cesáreo. Colón y Pinzón : Informe relativo a los pormenores del descubrimiento del Nuevo Mundo presentado a la Real Academia de la Historia. Madrid: Imprenta y Fundición de Manuel Tello, 1883.

Ferrer I Mallol, Maria Teresa. “Corso y piratería entre Mediterráneo y Atlántico en la Baja Edad Media”. CSIC: Institució Milà i Fontanals.

and Arcadi Garcia I Sanz. "Assegurances i canvis marítimis medievals a Barcelona." Institut d'Estudis Catalans.

Premi Ferran Armengol i Tubau, 1974. Barcelona, 1983.

Hernández Pinzón Y Ganzinotto, José. Vicente Yáñez Pinzón, Sus Viajes y Descubrimientos. Madrid: Imprenta del Ministerio de Marina, , 1920.

Hinojosa Montalvo, José. Pirateria y corso en la Edad media valenciana.

Majó Framis, Ricardo. “Los Pinzones.” Editorial Gran Capitán. Madrid, 1947.

Manzano Y Manzano, Juan. "Los Pinzones y el Descubrimiento de América.. Instituto de Cooperación Iberoamericana. Ediciones de Cultura Hispánica. Madrid, 1988.

Merrill, Charles J. Colom of Catalonia - Origins of Christopher Columbus Revealed. Spokane, Washington: Demers Books, 2008.

Morales, Padrón Francisco. "Las relaciones entre Colón y Martín Alonso Pinzón.”.Actas del Congreso de Americanistas de Lisboa, vol. 3 (1961), 433-442. Revista de Indias N.83 (1961) Espasa Calpe S.A., 1962.

Manual de Historia Universal Tomo V, Historia de América. Editorial

Rigaud, Philippe. Letras de la Costiera - Pirates et corsaires dans les mers de Provence XVe - XVIe siècles. Paris: Éditions du Comité des travaux historiques et scientifiques CTHS, , 2006.

Rodriquez Liañez, Laureano. "Moguer y Palos en la época del descubrimiento : Documentos para su historia en el registro del sello de corte del Archivo General de Simancas." Actas XI Jornadas de Andalucía y América. Huelva, 1993.

Ryder, Alan. The Wreck of Catalonia - Civil War in the Fifteenth Century . Oxford: Oxford University Press, 2007.

Solsona Climent, Francisca. "Aspectos de la dominación angevina en Cataluña, 1466-1472”. (La participación italiana y francesa en la revolución contra Juan II de Aragón). Cuadernos de Historia Jerónimo Zurita 14-14,1952, 31. 1983.

Unali, Anna. Marinari, pirate e corsari catalani nel Basso Medioevo. Bologna,

Vascáno, Antonio. Ensayo biográfico del célebre navegante y consumado cosmógrafo Juan de la Cosa. Madrid: Tipografía de V. Faure, 1892. 